Int. J. Med. Surg. Sci.,

2(4):635-641, 2015.

\title{
ADAM17 As Inducer of Male Germ Cell Apoptosis
}

\author{
ADAM17 como Inductor de la Apoptosis \\ de Células Germinales Masculinas
}

Ricardo D. Moreno*

MORENO, R. D. ADAM17 as inducer of male germ cell apoptosis. Int. J. Med. Surg. Sci, 2(4):635-641, 2015.

SUMMARY: Apoptosis during mammalian spermatogenesis is important to control sperm output and to eliminate damaged unwanted cells. A deregulation in apoptosis rate has deleterious consequences and leads to low sperm production. Apoptosis in spermatogenesis has been widely studied, but the mechanism by which it is induced under physiological or pathological conditions has not been clarified. We have recently identified the metalloprotease ADAM17 (TACE) as a putative physiological inducer of germ cell apoptosis. ADAM17 is widely distributed enzyme in many tissues, its main function is to shed (release) its substrates, which leads to the activation of different signaling pathways according to the cellular context. However, in spermatogenesis, ADAM17 is involved in the control or induction of germ cell apoptosis, this seems to be unique and may reflect the complexity of spermatogenesis. In this review I will focus on the published evidence that show how this enzyme involved in the control of germ cell apoptosis during physiological condition and in different insults such as heat stress, DNA damaging agent or endocrine disruptors.

KEY WORDS: ADAM17; Apoptosis; male germ cell.

\section{INTRODUCTION}

The aim of a mature mammalian spermatozoa is to reach the oocyte and then fuse with it in order to form a new zygote; this process is known as fertilization. Mammalian spermatozoa are formed in the testis and their production relies on physiological and environmental factors, which may attenuate, increase or even totally suppress testicular function. Germ cell apoptosis has been show to play an important role in controlling sperm output in many species, and its deregulation has been related to infertility (Lee et al., 1997, 1999, 2009; Feng et al., 1999; Weikert et al., 2004; Moreno et al., 2011). Recent reports have shown than global human sperm production is decreasing, which may be is caused by environmental toxicants that induce germ cell apoptosis (Sinawat, 2000). In the same way, modern life style and use of underwear has been proposed to produce an elevated scrotal temperature that may cause germ cell apoptosis, akin to transient heat stress $\left(43^{\circ} \mathrm{C}\right.$ for $15 \mathrm{~min}$ ) in testis (Lizama et al., 2009; Reyes et al., 2012). Many studies have shown the relevance of apoptosis in regulating spermatozoa output and eliminating damaged germ cells, particularly spermatocytes (Beumer et al., 1998; Allemand et al. 1999; Feng et al.; Elliott et al., 2010). Even more, in seasonal breeding mammals, apoptosis plays an important role in the massive germ cell depletion observed during the non-breeding season (Comitato et al., 2006). Finally, a massive germ cell death occurs in physiological conditions (constitutive apoptosis) during the first round of spermatogenesis, which is vital in order to establish a proper interaction between germ and Sertoli cells and to eliminate unwanted germ cells (Oakberg, 1956; Rodriguez et al., 1997; Moreno et al., 2006) Different experimental approaches

* Departamento de Fisiología, Pontificia Universidad Católica de Chile, Santiago, Chile. 
have pointed out that germ cells undergoing meiosis (spermatocytes) are the main target for apoptosis, and a smaller fraction of spermatogonia (Oakberg; Rodriguez et al., 1997; Jahnukainen et al., 2004; Moreno et al.). Therefore, apoptosis is important in physiological and pathological conditions, and the knowledge of the molecular mechanisms underlying this process may help to develop new pharmacological tools in order to modulate fertility.

\section{Apoptosis: The basics}

Apoptosis is a physiological process for killing cell and critical for the normal development and function of multicellular organisms (Rodriguez et al.; Tanuma, 1999; Riedl \& Shi, 2004). Abnormalities in cell death control contribute to a variety of diseases, including cancer, autoimmunity, and degenerative disorders. Signaling for apoptosis occurs through multiple independent pathways that are initiated either from triggering events within the cell or from outside the cell, for instance, by ligation of death receptors (Squier \& Cohen, 1996; Giammona et al., 2002; Coureuil et al., 2006; Ott et al., 2007; Degterev \& Yuan, 2008). All apoptosis signaling pathways converge on a common machinery of cell destruction that is activated by a family of cysteine proteases (caspases) that cleave proteins at aspartate residues. Dismantling and removal of doomed cells is accomplished by proteolysis of vital cellular constituents, DNA degradation, and phagocytosis by neighboring cells (Salvesen, 2002; Vera et al., 2005; Kuribayashi et al., 2006). Cell death by apoptosis is a part of normal development and maintenance of homeostasis but is also involved in pathological situation associated with sterility. In the testis, apoptosis is such a common programmed event that $75 \%$ of germ cells are reduced by spontaneous apoptosis (Knudson et al., 1995; Kua \& Kuida, 2003). In the testis have been described two pathways for cell death mainly, the Fas/Fasl system and intrinsic apoptotic pathway. The first, Binding of Fas to its ligand FasL forms a highly stable supramolecular cluster which promotes processing and stabilization of caspase-8 (Francavilla et al., 2000, 2002; D'Alessio et al., 2001; Henkler etal., 2005). Once activated, caspase- 8 can activate the effector caspases-3 (Salvesen; Shi, 2002; Codelia et al., 2008), which degrades a large number of cellular proteins that finally kill the cell. The second, the intrinsic apoptotic pathway is activated by stress, starvation or radiation, and it starts with the assembly of a multimeric complex (apoptosome) involving Apaf-1, procaspase- 9 and cytochrome c. Once activated, caspase- 9 cleaves and activates caspases-3, ending with the death of the cell.

\section{Extracellular metalloproteases as inducers of germ cell apoptosis: A working model}

ADAM10 and ADAM17 are two widely expressed metalloproteases linked to the ectodomain release of not only of ligands, but also receptors such as: Notch, epidermal growth factor (EGFR), the p75 neurotrophin receptor (p75NTR) or c-kit (Blobel, 2005; White et al., 2005; White Laboratry Web Page, 2015). Despite that ADAM1, the first member of the ADAM family, was discovered in the testis, it was not until 5 years later that TACE (the convertase of tumor necrosis factor-alpha) was recognized as a member of the metalloprotease family (Black et al., 1997). Since then, TACE/ADAM17 has been established as a key protease in mammalian development. Several studies have shown that the receptor tyrosine kinase c-kit is a substrate of ADAM17 (Cruz et al., 2004). This receptor (ckit) is a glycosylated transmembrane protein of $145 \mathrm{kDa}$, that once bound to its ligand (SCF) initiates a signaling cascade leading to proliferation, differentiation, migration and survival (Bedell \& Mahakali Zama, 2004; Matsui et al., 2004; Ronnstrand, 2004). In studies with cultured stem cells derived from mastocytes and umbilical cord endothelial cells, it has been found release of c-kit ectodomain dependent on TACE/ ADAM17 activity (Bedell \& Mahakali Zama; Matsui et al.). Moreover, embryonic cells showed a significant increase in apoptosis after being incubated with PMA, a phorbol ester known to activate PKC, but not in cells expressing a catalytically inactive mutant of TACE/ADAM17 (Cruz et al.). This result suggests a strong link between TACE/ADAM17, the processing of c-kit ectodomain and activation of apoptosis. C-kit is expressed in spermatogonia and spermatocyte and bind to its ligand bear by the sustentocyte. Our own data shows that germ cell undergoing apoptosis lack the extracellular domain of c-kit and in vivo PMA induces apoptosis in germ cells of 21-day old rat, which was prevented when a pharmacological inhibitor of ADAM17 was present 
at the time of PMA administration (Lizama et al., 2010c). ADAM17, but not ADAM10 is upregulated in germ cell undergoing physiological apoptosis, and pharmacological inhibitors of ADAM17 are able to significantly prevent physiological apoptosis. Overall, these results uncover a new a role for ADAM17 as a key physiological regulator of germ cell apoptosis during mammalian spermatogenesis.

External insults that trigger germ cell apoptosis are also related to ADAM17/ADAM10 activation: Interestingly, external insults that induce germ cell apoptosis could also induce activation of ADAM17, suggesting that this enzyme is at the center of different stress events that lead to apoptosis (Lizama et al., 2011b; Urriola-Munoz et al., 2014a, 2014b). An in vitro study show that etoposide, an anti-cancer drug that in vivo promotes germ cell dead, induce apoptosis of two cell lines derived from germ cells (GC-1 and GC-2). Interestingly, etoposide induces upregulation of mRNA and protein levels of ADAM10 and ADAM17. Accordingly, apoptosis could be prevented by a pharmacological inhibitor of ADAM10 and ADAM10 (Lizama et al. 2011a). In vivo, etoposide also induces activation of both metalloproteases suggesting similarities in this mechanism (Codelia et al., 2008, 2010; Ortiz et al., 2009). On the contrary, heat stress does not induces ADAM10 or ADAM17 activation, suggesting that not all the insults that induce germ cell apoptosis induce metalloprotease activation.

Recently it has been shown that several environmental endocrine disruptors such as Bisphenol-A (BPA) and nonylphenol (NP) induce germ cell apoptosis (Urriola-Munoz et al., 2014a). BPA and NP xenoestrogens are produced in larger volume worldwide as inducers of polymerization and they can be found in plastics, toys, food cans, cosmetics, etc. (Lagos-Cabre \& Moreno, 2012). These are artificial compounds having structural and functional similarity to estrogens, and also have estrogenic i.e. deregulate the hormonal balance of animals and humans, disrupting, estrogen-dependent reproductive (Park et al., 2009). However, xenoestrogens have a low affinity to genomic estrogen receptor (ERa and ERbeta) compared with estradiol 17ß (Gould et al., 1998), but still may affect the functions and development in animals at low concentrations.
The increase of xenoestrogens in the environment has raised concerns about the importance of these on human health, because they have been detected in human samples such as serum, urine, amniotic fluid, breast milk, semen, etc. (Inoue et al., 2002; Calafat et al., 2005; Swan et al., 2005; Main et al., 2006). And they have been linked to a decrease in ano-genital distance in sperm quality and fertility of man (Swan et al.).

There is a large volume of information regarding the disruption generated by BPA or NP in spermatogenesis using animal studies (LagosCabre \& Moreno). A decrease in the weight of testis, epididymis and sperm count has been observed in rats treated with up to $100 \mathrm{mg} / \mathrm{kg} /$ day of NF (Chitra et al., 2002). In addition, it decreases count and motility of sperm in adulthood when male rats are treated from 100$1600 \mathrm{mg} / \mathrm{kg} /$ day BFA during the neonatal period (Salian et al., 2009).

The decrease in number of sperm count in rats treated with xenoestrogens relates to an increase in germ cell apoptosis because of an activation of caspase- 3 in germ and Leydig cells, increased levels of Fas in germ cells and FasL in Sertoli cells and increased TUNEL positive cells (Watanabe et al., 2004; Tomasini et al., 2008; Hu et al., 2013). With respect to humans, there has been a high correlation between levels of BPA in urine and sperm abnormalities (motility, viability, count and sperm concentration and DNA fragmentation), suggesting that BPA and NP induce apoptosis of germ cells in humans (Meeker \& Ferguson, 2011). Therefore, given the ubiquitous distribution of these compounds in plastic products used by humans, it is important to clarify its mechanism of action and also to generate new pharmacological tools for infertility.

Recently it has been shown that the treatment with BPA or NP induces activation of ADAM17 but not ADAM10 in 21-days old rat. Accordingly, the apoptosis (mainly spermatocytes) was prevented when rats were previously treated with an ADAM17 but not ADAM10 pharmacological inhibitor (Urriola-Munoz et al., 2014a). In vitro, BPA and NP promote the shedding of TNF- $\alpha$ in cultured sustentocytes, suggesting that effectively they induce activation 
of ADAM17. Interestingly, BPA and NP induce shedding of neuregulin (another substrate of ADAM17) at similar concentration found in human fluids, suggesting that it might be possible that in vivo these compounds could affect this enzyme.

\section{Final considerations}

Apoptosis during spermatogenesis seems to be important to control the proper progression of germ cell development and the ration between germ cells to sustentocyte. However, to understand the physiological basis of this process help us understand its role in different pathological condition that may affect system beyond reproductive organs. The available data show that under physiological conditions, germ cell death could be considered as a bona fide apoptosis process, which seem to be regulated by ADAM17. Interestingly, despite the wide distribution of this enzyme, this is the only reported case where it is involved in apoptosis.
Other reports have shown its involvement in cell signaling, differentiation, inflammation or cell degeneration. Thus, it seems that male germ cells are unique in the mechanisms used to regulate apoptosis.

These data raise several questions such as: Which is/are the physiological substrate(s) shedding by ADAM 17 during germ cell apoptosis? How ADAM17 is activated under physiological conditions? How ADAM17 is activated under pathological conditions? Is there any physiological role for ADAM17 in mammalian spermatogenesis?

\section{ACKNOWLEDGMENTS}

This work is dedicated to the contribution of Professor Eduardo Bustos-Obregón to my understanding of the process of spermatogenesis and his passion for science.

MORENO, R. D. ADAM17 como inductor de la apoptosis de células germinales masculinas. Int. J. Med. Surg. SCi., 2(4):635-641, 2015.

RESUMEN: La apoptosis durante la espermatogénesis en mamíferos, es importante para controlar la salida de espermatozoides y para eliminar las células dañados no deseadas. Una desregulación en la tasa de apoptosis tiene consecuencias deletéreas y conduce a la baja producción espermática. La apoptosis en la espermatogénesis se ha estudiado ampliamente, pero el mecanismo por el que se induce en condiciones fisiológicas o patológicas no se esta clara. Recientemente hemos identificado a la metaloproteinasa ADAM17 (TACE) como una inductora de la apoptosis fisiológica en células germinales. La enzima ADAM17 está ampliamente distribuida en muchos tejidos, su función principal es liberar sus sustratos, lo que conduce a la activación de diferentes vías de señalización de acuerdo con el contexto celular. Sin embargo, en la espermatogénesis, ADAM17 está involucrada en el control o inducción de la apoptosis de las células germinales, esto parece ser único y puede reflejar la complejidad de la espermatogénesis. En esta revisión expone la evidencia de cómo esta enzima se muestra implicada en el control de la apoptosis de células germinales durante el estado fisiológico y en diferentes insultos tales como el estrés por calor, el agente que daña el ADN o los disruptores endocrinos.

PALABRAS CLAVE: ADAM17; La apoptosis; Célula germinal masculina.

\section{REFERENCES}

Allemand, I.; Anglo, A.; Jeantet, A. Y.; Cerutti, I. \& May, E. Testicular wild-type p53 expression in transgenic mice induces spermiogenesis alterations ranging from differentiation defects to apoptosis. Oncogene, 18(47):6521-30, 1999.

Bedell, M. A. \& Mahakali Zama, A. Genetic analysis of Kit ligand functions during mouse spermatogenesis. J. Androl., 25(2):188-99, 2004.
Beumer, T. L.; Roepers-Gajadien, H. L.; Gademan, I. S.; van Buul, P. P.; Gil-Gomez, G.; Rutgers, D. H. \& de Rooij, D. G. The role of the tumor suppressor p53 in spermatogenesis. Cell Death Differ., 5(8):669-77, 1998.

Black, R. A.; Rauch, C. T.; Kozlosky, C. J.; Peschon, J. J.; Slack, J. L.; Wolfson, M. F.; Castner, B. J.; Stocking, K. L.; Reddy, P.; Srinivasan, S.; Nelson, 
N.; Boiani, N.; Schooley, K. A.; Gerhart, M.; Davis, R.; Fitzner, J. N.; Johnson, R. S.; Paxton, R. J.; March, C. J. \& Cerretti, D. P. A metalloproteinase disintegrin that releases tumour-necrosis factoralpha from cells. Nature, 385(6618):729-33, 1997.

Blobel, C. P. ADAMs: key components in EGFR signalling and development. Nat. Rev. Mol. Cell Biol., 6(1):3243, 2005.

Calafat, A. M.; Kuklenyik, Z.; Reidy, J. A. ; Caudill, S. P.; Ekong, J. \& Needham, L. L. Urinary concentrations of bisphenol A and 4-nonylphenol in a human reference population. Environ. Health Perspect., 113(4):391-5, 2005.

Codelia, V. A.; Cisterna, M.; Alvarez, A. R. \& Moreno, R. D. p73 participates in male germ cells apoptosis induced by etoposide. Mol. Hum. Reprod., 16(10):734-42, 2010.

Codelia, V. A.; Cisternas, P. \& Moreno, R. D. Relevance of caspase activity during apoptosis in pubertal rat spermatogenesis. Mol. Reprod. Dev., 75(5):8819, 2008.

Comitato, R.; Esposito, T.; Cerbo, G.; Angelini, F.; Varriale, B. \& Cardone, A. Impairment of spermatogenesis and enhancement of testicular germ cell apoptosis induced by exogenous all-transretinoic acid in adult lizard Podarcis sicula. J. Exp. Zool. A Comp. Exp. Biol., 305(3):288-98, 2006.

Coureuil, M.; Fouchet, P.; Prat, M.; Letallec, B.; Barroca, V.; Dos Santos, C.; Racine, C. \& Allemand, I. Caspaseindependent death of meiotic and postmeiotic cells overexpressing p53: calpain involvement. Cell Death Differ., 13(11): 1927-37, 2006.

Cruz, A. C.; Frank, B. T.; Edwards, S. T.; Dazin, P. F.; Peschon, J. J. \& Fang, K. C. Tumor necrosis factoralpha-converting enzyme controls surface expression of c-Kit and survival of embryonic stem cell-derived mast cells. J. Biol. Chem., 279(7):5612-20, 2004.

Chitra, K. C.; Latchoumycandane, C. \& Mathur, P. P. Effect of nonylphenol on the antioxidant system in epididymal sperm of rats. Arch. Toxicol., 76(9):545$51,2002$.

D'Alessio, A.; Riccioli, A.; Lauretti, P.; Padula, F.; Muciaccia, B.; De Cesaris, P. ; Filippini, A. ; Nagata, S. \& Ziparo, E. Testicular FasL is expressed by sperm cells. Proc. Natl. Acad. Sci. U. S. A., 98(6):331621, 2001.

Degterev, A. \& Yuan, J. Expansion and evolution of cell death programmes. Nat. Rev. Mol. Cell Biol., 9(5):378-90, 2008.
Elliott, M. R.; Zheng, S.; Park, D.; Woodson, R. I.; Reardon, M. A.; Juncadella, I. J.; Kinchen, J. M.; Zhang, J.; Lysiak, J. J. \& Ravichandran, K. S. Unexpected requirement for ELMO1 in clearance of apoptotic germ cells in vivo. Nature, 467(7313):333-7, 2010.

Feng, H. L. ; Sandlow, J. I. ; Sparks, A. E.; Sandra, A. \& Zheng, L. J. Decreased expression of the c-kit receptor is associated with increased apoptosis in subfertile human testes. Fertil. Steril., 71(1):859, 1999.

Francavilla, S.; D'Abrizio, P.; Cordeschi, G.; Pelliccione, F.; Necozione, S. ; Ulisse, S.; Properzi, G. \& Francavilla, F. Fas expression correlates with human germ cell degeneration in meiotic and postmeiotic arrest of spermatogenesis. Mol. Hum. Reprod., 8(3):213-20, 2002.

Francavilla, S.; D'Abrizio, P.; Rucci, N.; Silvano, G.; Properzi, G.; Straface, E.; Cordeschi, G.; Necozione, S.; Gnessi, L.; Arizzi, M. \& Ulisse, S. Fas and Fas ligand expression in fetal and adult human testis with normal or deranged spermatogenesis. J. Clin. Endocrinol. Metab., 85(8):2692-700, 2000.

Giammona, C. J.; Sawhney, P.; Chandrasekaran, Y. \& Richburg, J. H. Death receptor response in rodent testis after mono-(2-ethylhexyl) phthalate exposure. Toxicol. Appl. Pharmacol., 185(2):119$27,2002$.

Gould, J. C.; Leonard, L. S.; Maness, S. C.; Wagner, B. L.; Conner, K.; Zacharewski, T.; Safe, S.; McDonnell, D. P. \& Gaido, K. W. Bisphenol A interacts with the estrogen receptor alpha in a distinct manner from estradiol. Mol. Cell. Endocrinol., 142(1-2):203-14, 1998.

Henkler, F.; Behrle, E.; Dennehy, K. M.; Wicovsky, A. ; Peters, N.; Warnke, C.; Pfizenmaier, K. \& Wajant, $\mathrm{H}$. The extracellular domains of Fas $L$ and Fas are sufficient for the formation of supramolecular FasL-Fas clusters of high stability. J. Cell Biol., 168(7): 1087-98, 2005.

Hu, Y.; Li, D.; Lu, Y. \& Han, X. Monobutyl phthalate induces the expression change of G-ProteinCoupled Receptor 30 in rat testicular Sertoli cells. Folia Histochem. Cytobiol., 51(1): 18-24, 2013.

Inoue, K.; Wada, M.; Higuchi, T.; Oshio, S.; Umeda, T.; Yoshimura, Y. \& Nakazawa, H. Application of liquid chromatography-mass spectrometry to the quantification of bisphenol $A$ in human semen. $J$. Chromatogr. B Analyt. Technol. Biomed. Life Sci., 773(2):97-102, 2002. 
Jahnukainen, K.; Chrysis, D. ; Hou, M.; Parvinen, M. ; Eksborg, S. \& Söder, O. Increased apoptosis occurring during the first wave of spermatogenesis is stage-specific and primarily affects midpachytene spermatocytes in the rat testis. Biol. Reprod., 70(2):290-6, 2004.

Knudson, C. M.; Tung, K. S.; Tourtellotte, W. G.; Brown, G. A. \& Korsmeyer, S. J. Bax-deficient mice with lymphoid hyperplasia and male germ cell death. Science, 270(5233):96-9, 1995.

Kua, C. Y. \& Kuida, K. Cell death in mammalian development. In: Yin, X. M. \& Dong, Z. (Eds.). Essential of Apoptosis: A guide for basic and Clinical Research. Totowa, Humana Press, 2003.

Kuribayashi, K.; Mayes, P. A. \& El-Deiry, W. S. What are caspases 3 and 7 doing upstream of the mitochondria? Cancer Biol. Ther., 5(7):763-5, 2006.

Lagos-Cabré, R. \& Moreno, R. D. Contribution of environmental pollutants to male infertily: a working model of germ cell apoptosis induced by plasticizers. Biol. Res., 45(1):5-14, 2012.

Lee, J.; Richburg, J. H.; Shipp, E. B.; Meistrich, M. L. \& Boekelheide, K. The Fas system, a regulator of testicular germ cell apoptosis, is differentially upregulated in Sertoli cell versus germ cell injury of the testis. Endocrinology, 140(2):852-8, 1999.

Lee, J.; Richburg, J. H. ; Younkin, S. C. \& Boekelheide, $\mathrm{K}$. The Fas system is a key regulator of germ cell apoptosis in the testis. Endocrinology, 138(5):2081-8, 1997.

Lee, J. D.; Lee, T. H.; Cheng, W. H. \& Jeng, S. Y. Involved intrinsic apoptotic pathway of testicular tissues in varicocele-induced rats. World J. Urol., 27(4):527-32, 2009.

Lizama, C.; Lagos, C. F.; Lagos-Cabré, R. ; Cantuarias, L.; Rivera, F.; Huenchuñir, P.; Pérez-Acle, T.; Carrión, F. \& Moreno, R. D. Calpain inhibitors prevent p38 MAPK activation and germ cell apoptosis after heat stress in pubertal rat testes. J. Cell Physiol., 221(2):296-305, 2009.

Lizama, C.; Ludwig, A. \& Moreno, R. D. Etoposide induces apoptosis and upregulation of TACE/ ADAM17 and ADAM10 in an in vitro male germ cell line model. Biochim. Biophys. Acta, 1813(1):120-8, 2011a.

Lizama, C. ; Rojas-Benítez, D. ; Antonelli, M.; Ludwig, A.; Bustamante-Marín, X.; Brouwer-Visser, J. \& Moreno, R. D. TACE/ADAM17 is involved in germ cell apoptosis during rat spermatogenesis. Reproduction, 140(2):305-17, 2010c.

Lizama, C. ; Rojas-Benitez, D. ; Antonelli, M.; Ludwig, A. \& Moreno, R. D. Involvement of TACE/ADAM17 and ADAM10 in etoposide-induced apoptosis of germ cells in rat spermatogenesis. J. Cell. Physiol., 227(2):829-38, 2011b.

Main, K. M. ; Mortensen, G. K. ; Kaleva, M. M. ; Boisen, K. A. ; Damgaard, I. N.; Chellakooty, M.; Schmidt, I. M.; Suomi, A. M.; Virtanen, H. E.; Petersen, D. V.; Andersson, A. M.; Toppari, J. \& Skakkebaek, N. E. Human breast milk contamination with phthalates and alterations of endogenous reproductive hormones in infants three months of age. Environ. Health Perspect., 114(2):270-6, 2006.

Matsui, J.; Wakabayashi, T.; Asada, M.; Yoshimatsu, K. \& Okada, M. Stem cell factor/c-kit signaling promotes the survival, migration, and capillary tube formation of human umbilical vein endothelial cells. J. Biol. Chem., 279(18):18600-7, 2004.

Meeker, J. D. \& Ferguson, K. K. Relationship between urinary phthalate and bisphenol A concentrations and serum thyroid measures in U.S. adults and adolescents from the National Health and Nutrition Examination Survey (NHANES) 2007-2008. Environ. Health Perspect., 119(10):1396-402, 2011.

Moreno, R. D.; Lizama, C.; Urzúa, N. ; Vergara, S. P. \& Reyes, J. G. Caspase activation throughout the first wave of spermatogenesis in the rat. Cell Tissue Res., 325(3):533-40, 2006.

Moreno, R. D.; Urriola-Muñoz, P. \& Lagos-Cabré, R. The emerging role of matrix metalloproteases of the ADAM family in male germ cell apoptosis. Spermatogenesis, 1(3):195-208, 2011.

Oakberg, E. F. A description of spermiogenesis in the mouse and its use in analysis of the cycle of the seminiferous epithelium and germ cell renewal. $\mathrm{Am}$. J. Anat., 99(3):391-413, 1956.

Ortiz, R. J.; Lizama, C.; Codelia, V. A. \& Moreno, R. D. A molecular evaluation of germ cell death induced by etoposide in pubertal rat testes. Mol. Hum. Reprod., 15(6):363-71, 2009.

Ott, M.; Gogvadze, V.; Orrenius, S. \& Zhivotovsky, B. Mitochondria, oxidative stress and cell death. Apoptosis, 12(5):913-22, 2007.

Park, S. H.; Kim, K. Y.; An, B. S.; Choi, J. H. ; Jeung, E. B.; Leung, P. C. \& Choi, K. C. Cell growth of ovarian 
cancer cells is stimulated by xenoestrogens through an estrogen-dependent pathway, but their stimulation of cell growth appears not to be involved in the activation of the mitogen-activated protein kinases ERK-1 and p38. J. Reprod. Dev., 55(1):239, 2009.

Reyes, J. G.; Farias, J. G.; Henriquez-Olavarrieta, S.; Madrid, E.; Parraga, M.; Zepeda, A. B. \& Moreno, R. D. The hypoxic testicle: physiology and pathophysiology. Oxid. Med. Cell Longev., 2012:929285, 2012.

Riedl, S. J. \& Shi, Y. Molecular mechanisms of caspase regulation during apoptosis. Nat. Rev. Mol. Cell Biol., 5(11):897-907, 2004.

Rodriguez, I.; Ody, C. ; Araki, K.; Garcia, I. \& Vassalli, P. An early and massive wave of germinal cell apoptosis is required for the development of functional spermatogenesis. E. M. B. O. J., 16(9):2262-70, 1997.

Rönnstrand, L. Signal transduction via the stem cell factor receptor/c-Kit. Cell. Mol. Life Sci., 61(1920):2535-48, 2004.

Salian, S.; Doshi, T. \& Vanage, G. Neonatal exposure of male rats to Bisphenol A impairs fertility and expression of sertoli cell junctional proteins in the testis. Toxicology, 265(1-2):56-67, 2009.

Salvesen, G. S. Caspases: opening the boxes and interpreting the arrows. Cell Death Differ., 9(1):35, 2002.

Shi, Y. Apoptosome: the cellular engine for the activation of caspase-9. Structure, 10(3):285-8, 2002.

Sinawat, S. The environmental impact on male fertility. J. Med. Assoc. Thai., 83(8):880-5, 2000.

Squier, M. K. \& Cohen, J. J. Calpain and cell death. Cell Death Differ., 3(3):275-83, 1996.

Swan, S. H.; Main, K. M.; Liu, F.; Stewart, S. L.; Kruse, R. L.; Calafat, A. M.; Mao, C. S.; Redmon, J. B.; Ternand, C. L.; Sullivan, S.; Teague, J. L. \& Study for Future Families Research Team. Decrease in anogenital distance among male infants with prenatal phthalate exposure. Environ. Health Perspect., 113(8): 1056-61, 2005.

Tanuma, S. I. Molecular mechanisms of apoptosis. In: Sluyser, M. (Eds.). Apoptosis in Normal Development and Cancer. Bristol, Taylor and Francis, 1996. pp. 39-61.
Tomasini, R.; Tsuchihara, K.; Wilhelm, M.; Fujitani, M.; Rufini, A.; Cheung, C. C.; Khan, F.; Itie-Youten, A. ; Wakeham, A.; Tsao, M. S.; Iovanna, J. L.; Squire, J. ; Jurisica, I.; Kaplan, D.; Melino, G. ; Jurisicova, A. \& Mak, T. W. TAp73 knockout shows genomic instability with infertility and tumor suppressor functions. Genes Dev., 22(19):2677-91, 2008.

Urriola-Muñoz, P.; Lagos-Cabré, R. \& Moreno, R. D. A mechanism of male germ cell apoptosis induced by bisphenol-A and nonylphenol involving ADAM17 and p38 MAPK activation. PLoS One, 9(12):e113793, 2014a.

Urriola-Muñoz, P.; Lizama, C.; Lagos-Cabré, R.; Reyes, J. G. \& Moreno, R. D. Differential expression and localization of ADAM10 and ADAM17 during rat spermatogenesis suggest a role in germ cell differentiation. Biol. Res., 47:31, 2014b.

Vera, Y.; Rodriguez, S.; Castanares, M.; Lue, Y.; Atienza, V.; Wang, C.; Swerdloff, R. S. \& Sinha Hikim, A. P. Functional role of caspases in heat-induced testicular germ cell apoptosis. Biol. Reprod., 72(3):516-22, 2005.

Watanabe, H.; Suzuki, A.; Goto, M.; Lubahn, D. B.; Handa, H. \& Iguchi, T. Tissue-specific estrogenic and non-estrogenic effects of a xenoestrogen, nonylphenol. J. Mol. Endocrinol., 33(1):243-52, 2004.

Weikert, S. ; Schrader, M.; Müller, M.; Krause, H. \& Miller, $\mathrm{K}$. Expression of the apoptosis inhibitor survivin in testicular tissue of infertile patients. Int. J. Androl., 27(3): 161-5, 2004.

White Lab. Table of the ADAMs. Charlottesville, University of Virginia, School of Medicine, Department of Cell Biology, 2015. Available from: h t t p : / / people.virginia.edu/ j w $7 \mathrm{~g} /$ Table_of_the_ADAMs.html.

White, J. M.; Bridges, L. ; DeSimone, D. ; Tomezuk, M. \& Wolfsberg, T. G. Introduction to the ADAM Family. In: Hooper, N. M.; Lendeckel, U. (Eds.). The ADASM family of Proteases. Dordrecht, Springer, 2005. pp.1-29.

Correspondence to:

Ricardo D. Moreno

Departamento de Fisiología

Facultad de Ciencias Biológicas

Pontificia Universidad Católica de Chile

Alameda 340

Santiago

CHILE

Received: 25-09-2015

Email: rmoreno@bio.puc.cl 